\title{
Phytosociological and Environmental Analysis of a Rocky Outcrop Located in Caldas County, Minas Gerais State, Brazil
}

\author{
João Paulo de Lima Braga ${ }^{1}$, Sarah França Andrade ${ }^{2} \&$ Richieri Antonio Sartori ${ }^{3}$
}

Recebido em 15/10/2019 - Aceito em 27/04/2020

\author{
Jardim Botânico de Poços de Caldas, Brasil <braga.joao@gmail.com> \\ 2 PUC-Rio, Brasil <sarahfandrade@gmail.com> \\ 3 Departamento de Biologia - PUC-Rio, Rua Marquês de São Vicente 225, Prédio Pe. Leonel Franca, $7^{\circ}$ Andar, Rio de Janeiro/RJ, Brasil. CEP: \\ 22.451-900 <richierisartori@puc-rio.br>
}

\begin{abstract}
The Atlantic Forest and Cerrado are domains of Brazil. We should pay more attention to the lesser assessed points in these biomes, as well as to their rocky outcrops. These sites are under great anthropogenic pressure due to the mineral exploitation present. This results in environmental degradation and loss of species that have not yet been studied. In the present study we aimed to characterize the structure and composition of a rocky outcrop in order to provide aids for the creation of protected areas and on the adoption of management techniques in areas degraded by mining activities. In total, we surveyed vegetation and environmental conditions in 10 plots $(50 \times 2 \mathrm{~m})$ allocated in the Environmental Protection Area of Pedra Branca Ecological Sanctuary, MG. We found 60 species distributed within 30 families and 52 genera, and diversity of 2.83 nats/ind. The most important family was Orchidaceae, which was followed by Poaceae, Polypodiaceae, Bromeliaceae and Piperace. The most important species were Cyperus coriifolius, Brasiliorchis picta, Tibouchina heteromalla, Paspalum notatum and Aechmea distichantha. The area has a higher Shannon diversity index ( $\left.\mathrm{H}^{\prime}\right)$ than other quartzite outcrops.
\end{abstract}

Keywords: Granite; inselberg; pedra branca; rocky-outcrop; xerophyte-vegetation.

\section{Análise Fitossociológica e Ambiental de um Afloramento Rochoso Localizado no Município de Caldas, Minas Gerais, Brasil}

RESUMO - A Mata Atlântica e o Cerrado são biomas considerados como hotspots de diversidade existentes no Brasil. Apesar de haver uma série de estudos nesses biomas, ainda restam vários pontos pouco avaliados; por exemplo, os afloramentos rochosos. Esses locais estão sob grande pressão antropogênica devido às suas composições mineralógicas. O objetivo do presente estudo foi caracterizar a estrutura e composição de um afloramento rochoso no município de Caldas e, assim, planejar estudos sobre a criação de áreas protegidas e a adoção de técnicas de manejo em áreas degradadas pelas atividades de mineração. O estudo foi realizado na Área de Proteção Ambiental do Santuário Ecológico de Pedra Branca, MG. No total, foram alocadas 10 parcelas $(50 \times 2 \mathrm{~m})$ onde a vegetação e as condições ambientais foram inventariadas. Foram encontradas 60 espécies, distribuídas em 30 famílias e 52 gêneros e diversidade de Shannon de 2,83 nats/ind. A família mais relevante foi Orchidaceae, seguida por Poaceae, Polypodiaceae, Bromeliaceae e Piperace. As espécies mais importantes foram Cyperus coriifolius, Brasiliorchis picta, Tibouchina heteromalla, Paspalum notatum e Aechmea distichantha. A área possui maior índice de diversidade de Shannon ( $\left.\mathrm{H}^{\prime}\right)$ do que outros afloramentos de quartzito.

Palavras-chave: Granito; inselberg; pedra branca; afloramento rochoso; vegetação xerofítica. 


\title{
Análisis Fitosociológico y Ambiental de un Afloramiento Rocoso Ubicado en el Condado de Caldas, Estado de Minas Gerais, Brasil
}

\begin{abstract}
RESUMEN - El Bosque Atlántico y el Cerrado son biomas considerados puntos críticos de diversidad en Brasil. Aunque hay varios estudios en estos biomas, todavía hay algunos puntos mal evaluados, como los afloramientos rocosos. Estos sitios están bajo una gran presión debido a sus composiciones mineralógicas y la falta de investigación. El objetivo del presente estudio fue caracterizar la estructura y composición de un afloramiento rocoso en el municipio de Caldas y, por lo tanto, planificar estudios sobre la creación de áreas protegidas y la adopción de técnicas de manejo en áreas degradadas por las actividades mineras. El estudio se llevó a cabo en el Área de Protección Ambiental del Santuario Ecológico Pedra Branca, MG. En total, se asignaron 10 parcelas $(50 \times 2 \mathrm{~m})$ donde se inventariaron la vegetación y las condiciones ambientales. Encontramos 60 especies distribuidas en 30 familias y 52 géneros y diversidad de Shannon de 2.83 nats/ind. La familia más importante fue Orchidaceae, seguida de Poaceae, Polypodiaceae, Bromeliaceae y Piperace. Las especies más importantes fueron Cyperus coriifolius, Brasiliorchis picta, Tibouchina heteromalla, Paspalum notatum y Aechmea distichantha. El área tiene un índice de diversidad de Shannon ( $\left.\mathrm{H}^{\prime}\right)$ más alto que otros afloramientos de cuarcita.
\end{abstract}

Palabras clave: Granito; inselberg; piedra blanca; afloramiento rochoso; vegetación xerofítica.

\section{Introduction}

The Atlantic Forest is one of the most threatened biomes on Earth, being considered one of the world biodiversity hotspots given its exceptionally high levels of diversity and endemism (Myers et al. 2000). Despite being relatively wellstudied as compared to other biomes in Brazil, much of its area remains poorly known, such as the rocky outcrops. These outcrops harbor a peculiar vegetation that develops under adverse soil, temperature and humidity conditions (Giuliettiet et al. 1997). According to Ab'Saber (2003), these environments can be nominated as relict or vegetation refuges. Yet, according to Groger \& Barthlott (1996), they can be Xeric Islands, where a species or plant community is surrounded by several sections of other ecosystems or phytophysiognomies.

In Poços de Caldas region, species are adapted to physiological, morphological and reproductive conditions, and their communities have great structural and floristic peculiarities (Porembski et al. 1997, Gibson et al. 2012). The soil in these locations also has peculiarities, in addition to toxic elements that influence current plant communities (Siefert et al. 2012; Vleminckx et al. 2015). The soils are mainly made up of Cambisols and Neossols (Moraes \& Jiménez-Rueda 2008) and have reduced nutritional levels due to the sources of origin. In addition, it exhibits low levels of exchangeable bases and base saturation. (Fernandes et al. 2003).

Due to their great mineralogical potential, rocky outcrops have been exploited since colonial period in Brazil, experiencing exponential increase in anthropic pressure in the last century (IBRAM 2003). Thus, many species have suffered drastic reduction in their habitat (Pinto et al. 2004). These losses led to real genetic-erosion risk, even to species extinction, mainly in tropical biomes (Pinto et al. 2004). Landscape conservation is of paramount importance for the maintenance of ecological processes and ecosystem biodiversity (Salles et al. 2019).

Meirelles (1996), Porembski et al. (1998) and Safford \& Martinelli (2000) highlighted that works on floristic composition and ecological characteristics of Brazilian granitoid rocky florals are rare in the specialized literature. Knowledge on rocky outcrop-associated vegetation provided by phytosociological surveys is a source of conservation support (Felfili et al. 1993, Castro 1994, Scarano 2007). It also provides important information for the assessment of anthropogenic impacts, for the creation of protected areas, and for the adoption of management techniques (Felfili \& Silva Júnior 2001).

The aims of the present study were to carry out a phytosociological analysis of a model area based on meteorological data collected throughout 
the study period, as well as to analyze humidity variation and the chemical composition of the used substrates. Studies similar to the current one can highlight the importance of conserving these sites due to the environmental issues Brazil has been going through because of the weakening of environmental laws.

\section{Material and Methods}

The study was carried out in the Environmental Protection Area APA Sanctuary Ecological of Pedra Branca (APAPB), which is located in Southwestern Caldas County, Southern Minas Gerais State (Figure 1). According to Köppen's classification, the climate in the region is of the Cwb type, subtropical in altitude, with mild and rainy summers and dry winters. Two types of soil are found in the area: 1 . Regolithic Neosol, which only occurs in areas associated with mixed slopes that present materials from the basement rock - found in the highest parts of the area -; and 2. Haplic Cambisol, which is considered an underdeveloped soil that accounts for characteristics of the original material that presents restrictions to agricultural land-use (Moraes 2008).

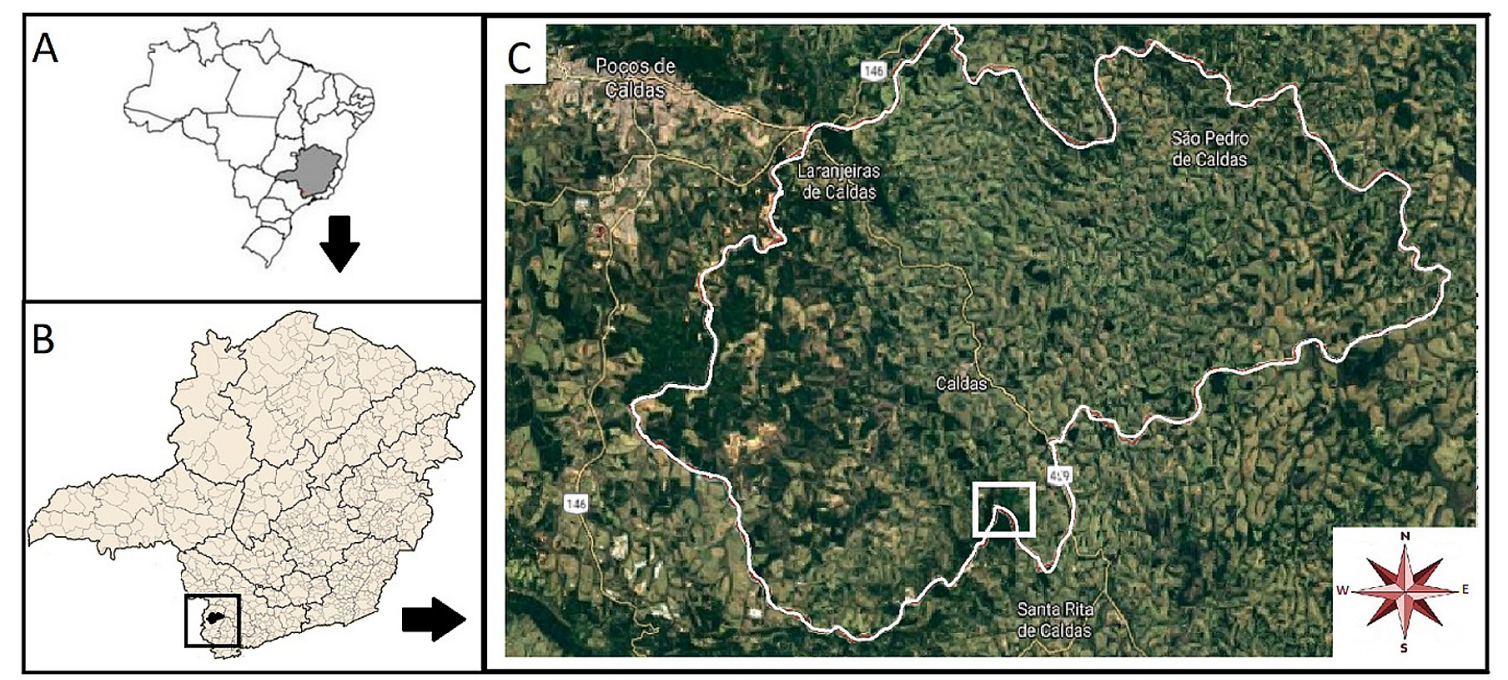

Figure 1 - Map of the study area showing the Ecological Sanctuary of Pedra Branca and the Municipal Biological Reserve of Serra da Pedra Branca in "C". Photo by João Paulo de Lima Braga.

According to Conforti et al. (2007), the following phytophysiognomies form the vegetative mosaic at APAPB: Altitude field and high elevation grasslands According to Elias et al. (2009) the area is covered by forest remnants, that corresponded to $13.6 \%$ (it comprised the phytophysiognomies and rock outcrops) $(7.8 \%)$ and to the anthropic area $(78.6 \%)$. Rocky outcrop areas accounting for $7.8 \%$ of the total APA area are considered ecological refugees (IBGE 2012) and the harbor for endangered species.

According to rainfall data for the region January 2016 was the rainiest month, it recorded rainfall index of $276.46 \mathrm{~mm}$. April was the driest month, it presented an index of $0.44 \mathrm{~mm}$.
February presented the highest mean temperature $\left(20.22{ }^{\circ} \mathrm{C}\right)$ and June showed the lowest one $\left(13.59^{\circ} \mathrm{C}\right)$. There were at least 3 large frosts with negative temperatures in June 2016. Vegetation is historically subject to significant drought periods from April to September in the APAPB region.

In total, 10 plots $(50 \mathrm{~m} \times 2 \mathrm{~m})$ were established within APAPB in order to sample vegetation cover on outcrops in natural areas - the total sample area was of 0.1 ha. Plots were perpendicular to the base ridge direction of the outcrop - they were spaced $50 \mathrm{~m}$ from each other (Figures $2 \mathrm{a}$ and $2 \mathrm{~b}$ ). Finally, subplots $\left(1 \mathrm{~m}^{2}\right)$ were subdivided every $10 \mathrm{~cm}$ (Figure 3), $-100 \mathrm{~m}^{2}$ were sampled per plot, and it totaled $1000 \mathrm{~m}^{2}$ of inventories. 


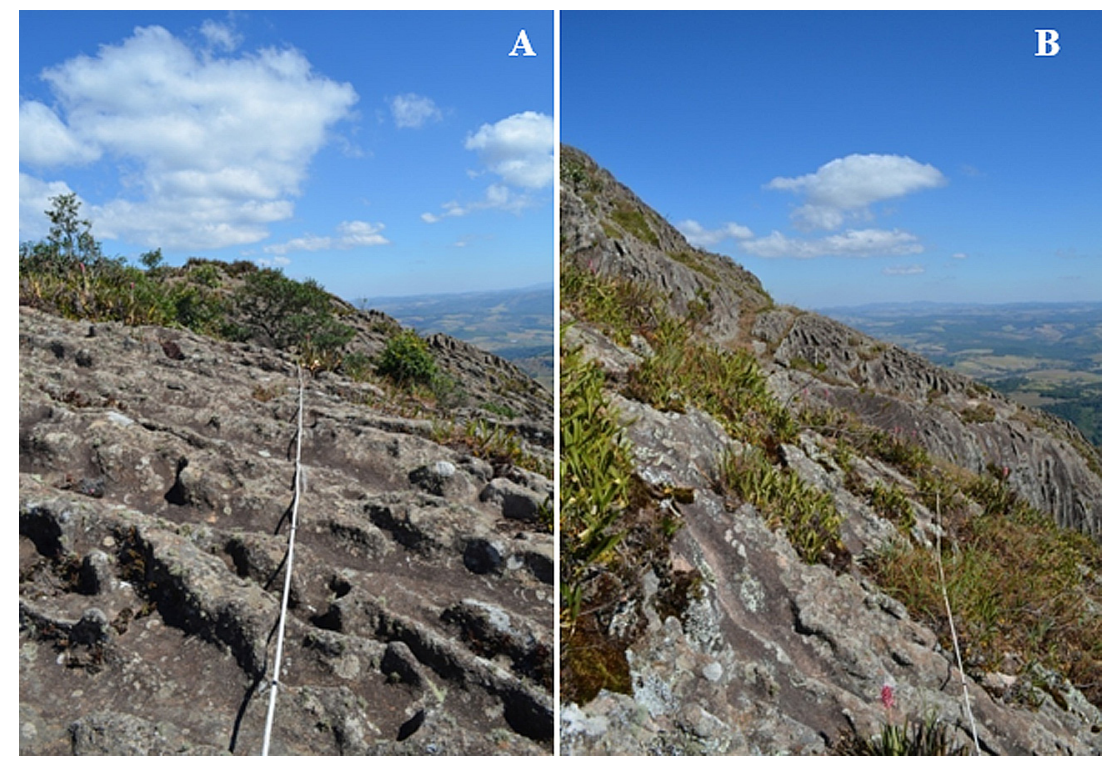

Figure 2 - Image of the allocation of plots in the outcrop. A: Exposed rock; B: Native vegetation. APA Pedra Branca Ecological Sanctuary, Caldas, MG. 2016. Photo by João Paulo de Lima Braga.

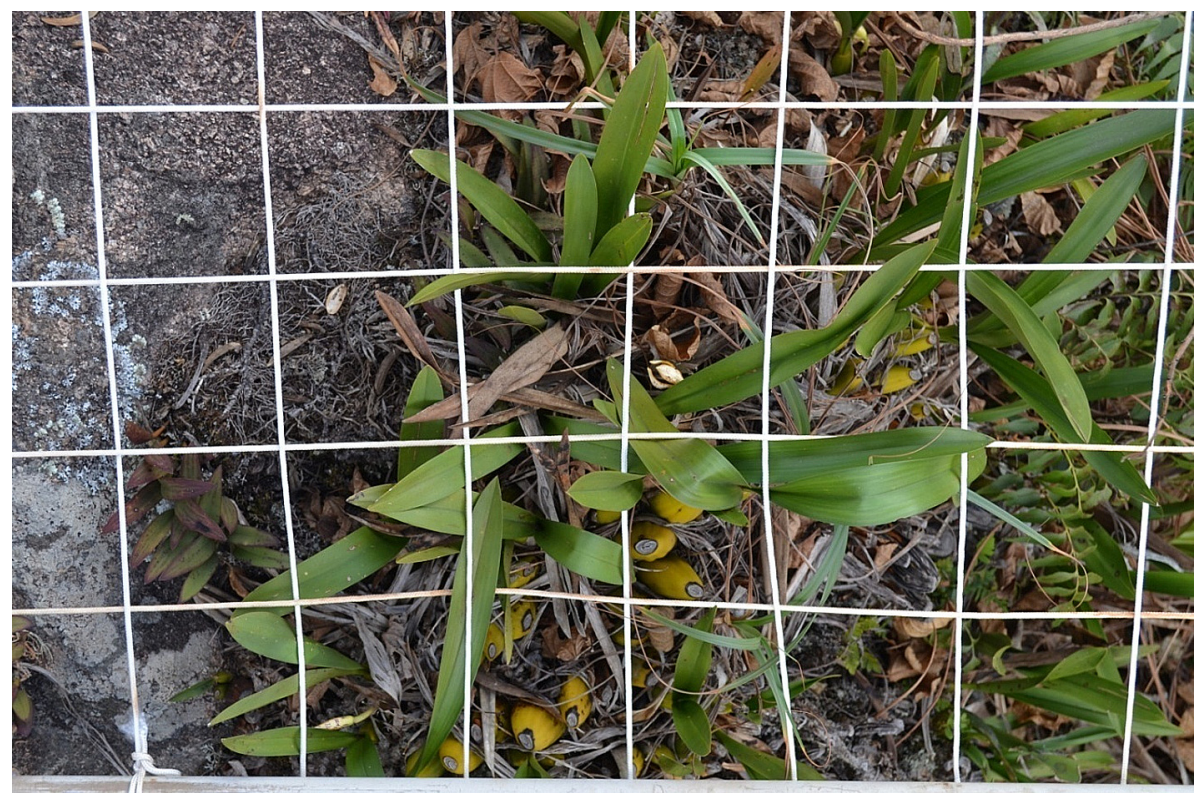

Figure 3 - Subdivision $(0.1 \times 0.1 \mathrm{~m})$ of the one $\mathrm{m}^{2}$ subplots. APA Pedra Branca Ecological Sanctuary, Caldas, MG. 2016. Photo by João Paulo de Lima Braga.

Phytosociological parameters 'frequency' (absolute and relative) and 'dominance' (absolute and relative) were calculated. Their values were used to calculate the Coverage Value (VC) of each species found in the site (Brower et al. 1998). Other authors have adopted this procedure in structural works about vegetation presenting the same vegetative characteristics (Menezes \& Araujo 1999,
Assumpção \& Nascimento 2000, Cordeiro 2005, Carvalho \& Sá 2011, Araujo et al. 2016). Only two relative parameters (frequency, coverage) were used to calculate VC - the final sum was equal to 200\% (Carvalho \& Sá 2011). The species of exotic grasses found in the area were not quantified at the time to determine the structural analysis. These species were taken into consideration in further 
analysis, they were quantified and categorized. Outcrop coverage rates of these same plots were estimated by considering the following categories: Rock, Native Vegetation, Dominated by exotic, Briophyte and Lichens.

The botanical material was collected, herborized and deposited in the Herbário Anders Fredrik Regnell (AR) of the Fundação Jardim Botânico de Poços de Caldas - duplicates were deposited in the Herbário do Instituto de Pesquisas Jardim Botânico do Rio de Janeiro (RB). Taxonomic identification was carried out through consultation in the specialized literature and through comparisons with herbarium material. Angiosperm Phylogeny Group III (APG III 2009) was adopted for the taxonomic classification of angiosperm families.

For comparison of nutrient contents, as well as $\mathrm{pH}$ and organic matter, samples of the substrates were collected monthly which at the end of the evaluation period formed a composite sample. Concomitantly, a compost sample was collected in the area where the plots of the phytosociological study were installed. The samples were sent to the Soil Laboratory of ESALQ/USP in Piracicaba, SP. The samples of the substrates were also used to quantify the humidity.

\section{Results and Discussion}

\section{Structural analysis of the area}

Sixty species, distributed into 30 families and 52 genera, were found in the APAPB. Orchidaceae (12 spp.) was the richest family with 12 species, followed by Poaceae (7 spp.),
Polypodiaceae (5 spp.), Bromeliaceae (3 spp.) and Piperace (3 spp.). It represents an addition of four species compared to previous surveys carried out in the same area (Rezende 2013). The predominance of species with herbaceous and shrubby habit, occurring in altitude fields, follows a pattern commonly observed in similar environments, in which vegetation is dominated by shrubs and small trees with several species of Poaceae, Orchidaceae, Bromeliaceae, and ferns (Safford 1999). The richest families found in this area are often cited as being the most representative in the predominantly rural areas of Minas Gerais (Giulietti et al. 1997, Pirani et al. 2003, Leoni \& Tinte 2004, Alves \& Kolbek 2009, Salimena et al. 2013). Orchidaceae is the richest family in the Atlantic Forest, and it is often referred as the most representative in highlands or rupestrian fields, such as Serra do Brigadeiro State Park (PESB) (Leoni \& Tinte 2004, Caiafa \& Silva 2005), Ibitipoca Estadual Park (PEI) (Menini-Neto et al. 2007) and Serra Negra (Abreu et al. 2011).

Cyperus coriifolius Boeckeler, Brasiliorchis picta (Hook.) RBSinger, Tibouchina heteromalla D. Don (D. Don), Paspalum notatum Flüggé, A. distichantha Lem., Octomeria crassifolia Lindl., Doryopteris ornithopus (Hook. and Baker) J.Sm. and Axonopus sp (Table 1) were the species presenting the highest values of importance (VC). These eight species have prevailed in the APAPB, recording VCs higher than 10 and occupying approximately $63 \%$ of it. In total, 18 species, whose VC ranged from 1 and 10 (31.4\% of VC), were intermediate. The 35 species considered rare presented VC lower than one and together they represent $5.7 \%$ of the total.

Table 1 - Species sampled in the rock outcrop of Rebio da Pedra Branca, Caldas, Minas Gerais. Phytosociological parameters: $\mathrm{NP}=$ number of plots with occurrence of the species; $\mathrm{FR}=$ relative frequency (\%); $\mathrm{RC}=$ relative coverage $(\%)$ and $\mathrm{CV}=$ cover value. Species ordered from CV. Caldas, MG. 2016.

\begin{tabular}{|l|l|c|c|c|c|}
\hline \multicolumn{1}{|c|}{ Specie } & Botanical Family & NP & FR & CR & VC \\
\hline Cyperus coriifolius Boeckeler & Cyperaceae & 195 & 9.92 & 15.8 & 25.76 \\
\hline Brasiliorchis picta (Hook.) R.B.Singer et al. & Orchidaceae & 96 & 4.88 & 14.2 & 19.14 \\
\hline Pleroma heteromalla D. Don (D. Don) & Melastomataceae & 200 & 10.17 & 8.63 & 18.80 \\
\hline Paspalum notatum Flüggé & Poaceae & 78 & 3.96 & 10.9 & 14.89 \\
\hline Aechmea distichantha Lem. & Bromeliaceae & 99 & 5.03 & 9.71 & 14.75 \\
\hline Octomeria crassifolia Lindl. & Orchidaceae & 80 & 4.07 & 7.27 & 11.34 \\
\hline
\end{tabular}




\begin{tabular}{|c|c|c|c|c|c|}
\hline Doryopteris ornithopus (Hook. \& Baker) J.Sm. & Pteridaceae & 151 & 7.68 & 2.91 & 10.60 \\
\hline Axonopus sp. & Poaceae & 76 & 3.86 & 6.58 & 10.45 \\
\hline Peperomia galioides Kunth & Piperaceae & 124 & 6.31 & 2.87 & 9.18 \\
\hline Eupatoriopsis hoffmanniana Hieron. & Asteraceae & 112 & 5.70 & 1.71 & 7.41 \\
\hline Scleria sp. & Cyperaceae & 83 & 4.22 & 2.47 & 6.70 \\
\hline Alstroemeria variegata M.C.Assis & Alstroemeriaceae & 104 & 5.29 & 1.30 & 6.59 \\
\hline Asplenium serra Langsd. \& Fisch. & Aspleniaceae & 74 & 3.77 & 1.64 & 5.40 \\
\hline Sinningia striata (Fritsch) Chautems & Gesneriaceae & 89 & 4.53 & 0.84 & 5.37 \\
\hline Schizachyrium sp. & Poaceae & 28 & 1.43 & 2.07 & 3.50 \\
\hline Croton hemiargyreus Müll.Arg. & Euphorbiaceae & 32 & 1.63 & 1.68 & 3.30 \\
\hline Mandevilla venulosa (Müll.Arg.) Woodson & Apocynaceae & 35 & 1.78 & 0.85 & 2.64 \\
\hline Epidendrum secundum Jacq. & Orchidaceae & 22 & 1.12 & 1.00 & 2.12 \\
\hline Bulbophyllum rupicolum Barb.Rodr. & Orchidaceae & 27 & 1.37 & 0.24 & 1.61 \\
\hline Sinningia magnifica (Otto \& A.Dietr.) Wiehler & Gesneriaceae & 23 & 1.17 & 0.32 & 1.49 \\
\hline Sisyrinchium vaginatum Spreng. & Iridaceae & 18 & 0.92 & 0.57 & 1.49 \\
\hline Microgramma squamulosa (Kaulf.) de la Sota & Polypodiaceae & 20 & 1.02 & 0.32 & 1.34 \\
\hline Calydorea campestris (Klatt) Baker & Iridaceae & 21 & 1.07 & 0.19 & 1.26 \\
\hline Trichanthecium cyanescens (Nees ex Trin.) Zuloaga \& Morrone & Poaceae & 6 & 0.31 & 0.93 & 1.24 \\
\hline Philodendron cordatum Kunth ex Schott & Araceae & 7 & 0.36 & 0.69 & 1.04 \\
\hline Tillandsia tenuifolia $\mathrm{L}$. & Bromeliaceae & 14 & 0.71 & 0.31 & 1.02 \\
\hline Prescottia montana Barb.Rodr. & Orchidaceae & 18 & 0.92 & 0.03 & 0.94 \\
\hline Vriesea sceptrum Mez & Bromeliaceae & 9 & 0.46 & 0.41 & 0.87 \\
\hline Peperomia oreophila Henschen & Piperaceae & 11 & 0.56 & 0.21 & 0.77 \\
\hline Tripogon spicatus (Nees) Ekman & Poaceae & 7 & 0.35 & 0.33 & 0.69 \\
\hline Stevia decussata Baker & Asteraceae & 12 & 0.61 & 0.07 & 0.68 \\
\hline Zygopetalum triste Barb.Rodr. & Orchidaceae & 5 & 0.25 & 0.34 & 0.59 \\
\hline Rhipsalis floccosa Salm-Dyck ex Pfeiff. & Cactaceae & 3 & 0.15 & 0.45 & 0.59 \\
\hline Bulbophyllum epiphytum Barb.Rodr. & Orchidaceae & 9 & 0.45 & 0.08 & 0.53 \\
\hline Myrcia obovata (O.Berg) Nied. & Myrtaceae & 2 & 0.10 & 0.42 & 0.52 \\
\hline Bulbophyllum exaltatum Lindl. & Orchidaceae & 8 & 0.40 & 0.08 & 0.49 \\
\hline Pecluma sp. & Polypodiaceae & 5 & 0.25 & 0.19 & 0.44 \\
\hline Pleopeltis pleopeltidis (Fée) de la Sota & Polypodiaceae & 7 & 0.35 & 0.08 & 0.44 \\
\hline Commelina erecta $\mathrm{L}$. & Coomelinaceae & 5 & 0.25 & 0.15 & 0.41 \\
\hline Dioscorea sp. & Dioscoreaceae & 7 & 0.35 & 0.05 & 0.41 \\
\hline Ipomoea regnellii Meisn. & Convolvulaceae & 6 & 0.30 & 0.09 & 0.40 \\
\hline Elaphoglossum burchellii (Baker) C.Chr. & Dryopteridaceae & 7 & 0.35 & 0.02 & 0.37 \\
\hline Doryopteris crenulans (Fée) Christ & Pteridaceae & 3 & 0.15 & 0.12 & 0.27 \\
\hline Bifrenaria harrisoniae (Hook.) Rchb.f. & Orchidaceae & 3 & 0.15 & 0.07 & 0.22 \\
\hline Hyptis sp. & Lamiaceae & 2 & 0.10 & 0.08 & 0.18 \\
\hline
\end{tabular}




\begin{tabular}{|l|l|c|c|c|c|}
\hline Handroanthus albus (Cham.) Mattos & Bignoniaceae & 3 & 0.15 & 0.01 & 0.16 \\
\hline Phlegmariurus regnellii (Maxon) B.Øllg. & Lycopodiaceae & 3 & 0.15 & 0.01 & 0.16 \\
\hline Andropogon bicornis L. & Poaceae & 1 & 0.05 & 0.10 & 0.15 \\
\hline Alternanthera brasiliana (L.) Kuntze & Amaranthaceae & 2 & 0.10 & 0.05 & 0.15 \\
\hline Melpomene sp. & Polypodiaceae & 2 & 0.10 & 0.04 & 0.14 \\
\hline Anemia villosa Humb. \& Bonpl. ex Willd. & Anemiaceae & 2 & 0.10 & 0.03 & 0.13 \\
\hline Chloris sp. & Poaceae & 1 & 0.05 & 0.05 & 0.10 \\
\hline Habenaria caldensis Kraenzl. & Orchidaceae & 1 & 0.05 & 0.03 & 0.08 \\
\hline Elaphoglossum itatiayense Rosenst. & Dryopteridaceae & 1 & 0.05 & 0.03 & 0.07 \\
\hline Peperomia tetraphylla (G.Forst.) Hook. \& Arn. & Piperaceae & 1 & 0.05 & 0.02 & 0.06 \\
\hline Asplenium praemorsum Sw. & Aspleniaceae & 1 & 0.05 & 0.01 & 0.06 \\
\hline Gomesa varicosa (Lindl.) M.W.Chase \& N.H.Williams & Orchidaceae & 1 & 0.05 & 0.01 & 0.06 \\
\hline Borreria sp. & Rubiaceae & 1 & 0.05 & 0.01 & 0.05 \\
\hline Epidendrum avicula Lindl. & Orchidaceae & 1 & 0.05 & 0.00 & 0.05 \\
\hline Serpocaulon vacillans (Link) A.R.Sm. & Polypodiaceae & 1 & 0.05 & 0.01 & 0.05 \\
\hline & & 1965 & 100 & 100 & 200 \\
\hline
\end{tabular}

Diversity value was 2.83 nats/ind. and equability was 0.64. Meirelles et al. (1999) found 1.74 to 2.96 nats/ind in different granitic outcrops in Rio de Janeiro. The area has Shannon diversity index $\left(\mathrm{H}^{\prime}\right)$ greater than the quartizitic outcrops in Chapada Diamantina and in Canga Outcrops at Serra do Espinhaço region. Conceição \& Giulietti (2002) found 2.79 nats/ind in a quartzitic outcrop in Chapada Diamantina. Our diversity values are comparable with those from other studies carried out in distinct outcrops. According to Rizzini (1979), plant communities in rocky outcrops often show lower species diversity than their surrounding ecosystems. However, due to isolation, they usually present high $\beta$ diversity (Burke 2003). Based on these results, the herein assessed site has considerable diversity, but we must also take into account the endemism of species found in this type of vegetation.

Most species in APAPB outcrops followed the pattern of rocky outcrops. In APAPB the floristic composition differed due to insulation caused by their exposure to rock lengthens. According to data recorded at the Botanical Garden of Poços de Caldas and field observations, many of these species did not occur in adjacent phytophysiognomies, as observed for species
C. coriifolius, Tibouchina heteromalla, Paspalum notatum, Octomeria crassifolia, Doryopteris ornithopus and Axonopus sp. However, some species, such as A. distichantha, S. magnifica, A. minarum and Philodendron cordatum, occured in rocky outcrops and in forests surrounding them. The fact that they have species that are not found in adjacent phytophysiognomies reinforces the importance given by Drummond et al. (2005), where in their study, they address the need for floristic inventories in the region, recognizing it as an important place for the conservation of the flora of Minas Gerais.

Outcrop coverage rates are as follow: Rock, $59.43 \%\left(594.3 \mathrm{~m}^{2}\right)$; Native Vegetation, $24.25 \%$ $\left(242.5 \mathrm{~m}^{2}\right)$; Exotic Species, $6.35 \%\left(63.5 \mathrm{~m}^{2}\right)$; Bryophytes, $3.72 \%\left(37.2 \mathrm{~m}^{2}\right)$; and Lichens, $6.25 \%$ $\left(62.5 \mathrm{~m}^{2}\right)$ - Figure 4.

Although it was possible observing flora representatives of syenitic outcrops in the region, RebioPB presented some signs of environmental degradation. The presence of exotic species, mainly of grasses belonging to genera Melinis spp. and Urochloa spp. (molasses Grass and Brachiaria, respectively), was worrisome because these species are quite aggressive and compete with the native species for space and resources. 


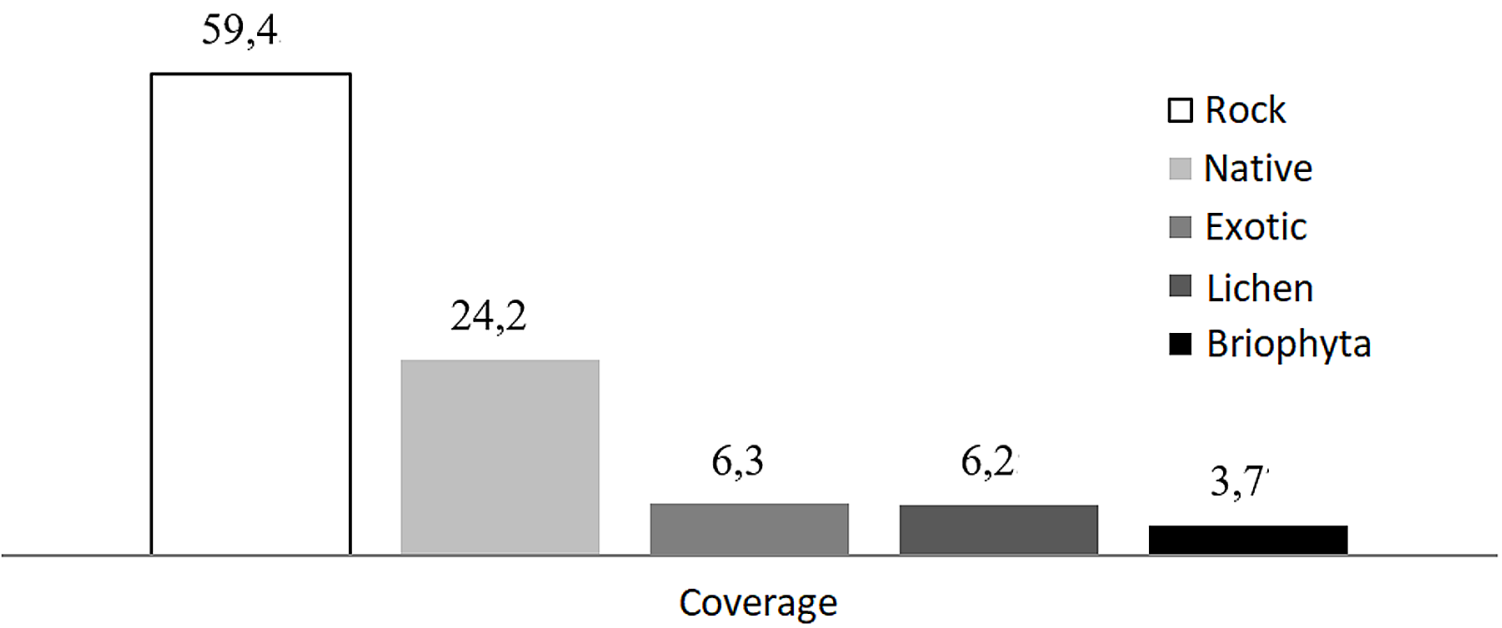

Figure 4 - Graph of the percentage of average coverage of rocky outcrops of the Environmental Protection Area Pedra Branca Ecological Sanctuary.

\section{Chemical analysis of substrates}

Both soil in the natural area and substrates used in the plots presented high acidity. Both soils presented very good organic matter content values. Mendonça (2013) considered that soil physical and chemical characteristics in canga outcrops are among the main factors limiting vegetation development. He also observed that soil in these areas is very acid and poor in nutrients, mainly in phosphorus and Magnesium. The "protossol" found in syenitic outcrops at APAPB also followed this pattern; however, it had very good organic matter content. This outcome mostly resulted from vegetation-fragment cycling. This process is of fundamental importance to nutrient supply in order to assure the maintenance of the ecosystem established in there.

Water scarcity is a limiting factor; species that have managed to adapt to this environmental feature survive over time and settle in rocky outcrops. Winter is the dry season, and it often records negative temperatures and frost events. Vegetation responds with vegetative part loss, dormancy of gems and reproductive part loss at this time of the year.

Mean rainfall influenced the survival of all species, except for $A$. distichanth. The highest mortality peaks of $A$. minarum, B. picta and
S. magnifica were recorded at the first drought period in April 2016, whereas the mortality peak of $C$. coriifolius occurred in the second drought period, between August and September 2016.

\section{Substrate humidity}

Figure 5 shows the mean substrate humidity during the evaluation period - its maximum value was recorded in January 2016. Humidity remained at levels close to $30 \%$ in the first drought period (April 2016), it rose in the following two months due to rainfall in May and June. Humidity decreased again after this period and reached its lowest level in September - treatment 01 recorded $12.45 \%$, treatment 02 recorded $4.90 \%$ and treatment 03 recorded $2.11 \%$. There was direct association between mean rainfall and substrate humidity. Time variation was statistically similar even when mean substrate humidity values were different.

\section{Final Considerations}

It is of utmost importance to maintain vegetation in sienitic outcrops at $\mathrm{APAPB}$ due to its environmental importance. Besides presenting a larger number of species than other environments 


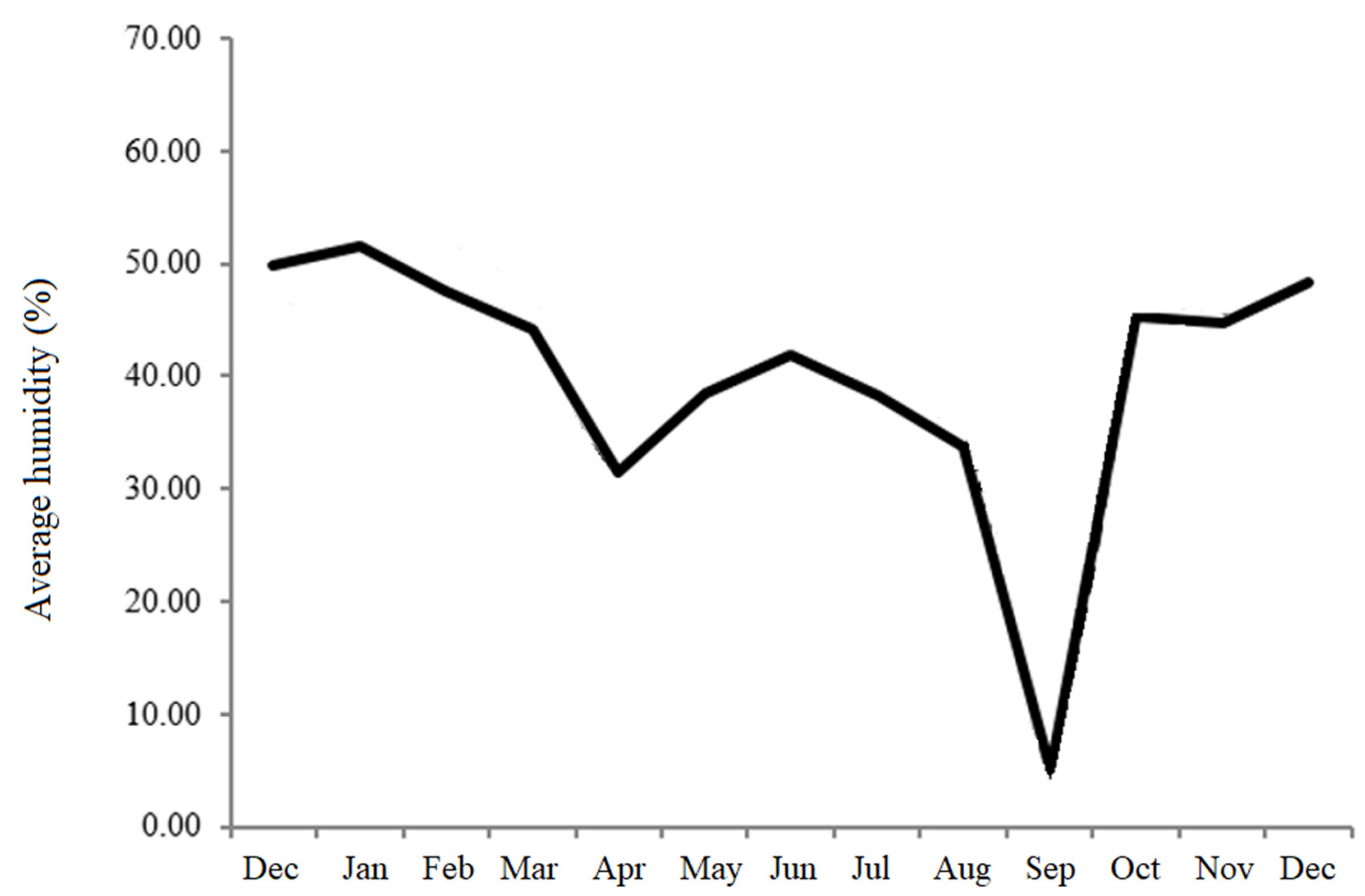

Figure 5 - Average moisture content (\%) of the substrate during the study period. Caldas, MG. 2016.

in Brazil, APAPB is home to an endemic species of the rocky outcrops considered critically endangered, namely: Phlegmariurus regnellii (Maxon) B.Øllg. (Lycopodiaceae); and to a recently described species that deserves attention, Alstroemeria variegata M.C. Assis (Alstroemeriaceae).

The analysis of outcrop cover showed that the largest portion of APAPB is formed by bare rock; it is followed by native vegetation, exotic vegetation, lichens and bryophytes. The existence of exotic species is a worrisome factor because APAPB is a conservation unit. Grasses belonging to genera Melinis spp. and Urochloa spp. (molasses Grass and Brachiaria, respectively) are aggressive species that compete with native species. Therefore, it is interesting to carry out regular monitoring and, if necessary, to adopt control measures of invasive species.

Further studies on conservation and restoration of areas like "Pedra Branca" are needed, mainly research using a larger number of species in these areas. Many floristic composition studies have been carried out in rocky outcrops in recent years, but little is known about the management of these canga species.

\section{Acknowledgement}

We thank the Botanical Garden of Poços de Calda for all technical support given to the study.

\section{Author Contribution Statement}

João P. L. Braga did the field work, set the plots, collected data and wrote the first version of the manuscript. Sarah França Andrade assisted in data analysis and helped writing the article. Richieri A. Sartori made the data analysis and helped writing and translating the article.

\section{References}

Ab'Saber AN. 2003. Os domínios da natureza no Brasil: potencialidades paisagísticas. Ateliê. 153p.

Abreu NL, Menini Neto L, Konno TUP. Orchidaceae das Serras Negra e do Funil, Rio Preto, Minas Gerais, e similaridade florística entre formações campestres $e$ florestais do Brasil. Acta. Bot. Bras, 25(1): 58-70, 2011.

Alves RJV, Kolbek J. Summit vascular flora of Serra de São José, Minas Gerais, Brasil. Check List, 5(1): 35-73, 2009. 
APG III. An update of the Angiosperm Phylogeny Group classification for the orders and families of flowering plants: APG III. Botanical Journal of the Linnean Society, 141: 399-436, 2009.

Araujo ACM, Silva ANF, Almeida Jr. EB. Caracterização estrutural e status de conservação do estrato herbáceo de dunas da Praia de São Marcos, Maranhão, Brasil. Acta Amazônica, 46(3): 247-258, 2016.

Assumpção J, Nascimento MT. Estrutura e composição florística de quatro formações vegetais de restinga no complexo lagunar Grussaí/Iquipari, São João da Barra, RJ, Brasil. Acta Botanica Brasilica, 14: 301-315, 2000.

Brower JE, Zar JH, Von Ende CN. 1998. Field \& laboratory methods for general ecology. 4 ed. Mc GrawHill. 273p.

Burke A. Inselbergs in changing world-global trends. Diversity and Distributions, 9(5): 375-383, 2003.

Caiafa AN, Silva AF. Composição florística e espectro biológico de um campo de altitude no Parque Estadual da Serra do Brigadeiro, Minas Gerais-Brasil. Rodriguésia, 56(87): 163-173, 2005.

Caponi HL, Fantin M, Gardênia T. 2007/ Avaliação dos impactos sobre o meio físico (biótico e abiótico) $e$ aspectos legais das mineradoras na região da Serra da Pedra Branca, Caldas, MG. Relatório Técnico apresentado ao CODEMA de Caldas, MG.

Carmo FF, Jacobi CM. A vegetação de canga no Quadrilátero Ferrífero, Minas Gerais: caracterização e contexto fitogeográfico. Rodriguésia, 64: 527-541, 2013.

Carvalho DA, Sá CFC. Estrutura do estrato herbáceo de uma restinga arbustiva aberta na APA de Massambaba, Rio de Janeiro, Brasil. Rodriguésia, 62: 367-378, 2011.

Castro AAJF. 1994. Composição florístico-geográfica (Brasil) e fitossociológica (Piauí-São Paulo) de amostras de cerrado. UNICAMP. 520p

Conceição AA, Giulietti AM. Composição florística e aspectos estruturais de campo rupestre em dois platôs no Morro do Pai Inácio, Chapada Diamantina, Bahia, Brasil. Hoehnea, 29(1): 37-48, 2002.

Conforti TB, Ramos E, Adami SF, Rosas PFC, Filho, J JB, Caponil HL \& Pardalis AA. 2007. Zoneamento Ambiental da APA "Santuário Ecológico da Pedra Branca", unidade de conservação municipal, Caldas, MG. Relatório Técnico apresentado ao CODEMA. 116p.

Cordeiro SZ. Composição e distribuição florística da vegetação herbácea em três áreas com fisionomias distintas na Praia do Peró, Cabo Frio, RJ, Brasil. Acta Botanica Brasilica, 19: 679-693, 2005.
Drummond GM, Martins CS, Machado ABM, Sebaio FA, Antonini Y. 2005. Biodiversidade em Minas Gerais, um atlas para sua conservação. 2 ed. Fundação Biodiversitas. 222p.

Elias RCL, Rezende MG, Malafaia Filho M, Alfenas GFM, Salimena FRG. 2009. Determinação das fitofisionomias da "APA Santuário Ecológico da Pedra Branca" Caldas, MG, por meio do NDVI (Índice de Vegetação da Diferença Normatizada). Mais um recurso para a conservação da biodiversidade? <http://www. seb-ecologia.org.br/2009/resumos_clae/239.pdf. > Acesso em: 19/11/2014.

Felfili JM, Silva Júnior MC (orgs.) 2001. Biogeografia do Bioma Cerrado. Estudo fitofisionômico na Chapada do Espigão Mestre do São Francisco. UnB. 152p.

Felfili JM, Silva Júnior MC, Rezende AV, Machado BWT, Silva PEN, Hay JD. Análise comparativa da florística e fitossociologia da vegetação arbórea do cerrado sensu stricto na Chapada Pratinha, Brasil. Acta botanica Brasilica, 6(2): 27-46, 1993.

Gibson N, Meissner R, Markey AS, Thompson WA. 2012. Patterns of plant diversity in ironstone ranges in arid south Western Australia. J. Arid Environ. 77, 25-31, 2012.

Giulietti AM, Pirani, JR, Harley RM. 1997. Espinhaço Range Region, Eastern Brazil, vol. 3. p. 397-404. In: Centres of plant diversity. A guide and strategy for their conservation. IUCN Publication Unity, Cambridge.

Gröger A, Barthlott W. Biogeography and diversity of the inselbergs (Laja) vegetation of southern Venezuela. Biodiversity Letters, 3: 165-179, 1996.

Instituto Brasileiro de Geografia e Estatística - IBGE. 2012. Manual Técnico da Vegetação Brasileira. 2 ed. IBGE. 145p.

Instituto Brasileiro de Mineração. 2003. Contribuição do IBRAM para o zoneamento ecológico-econômico e o planejamento ambiental de municípios integrantes da APASUL RMBH. 334p.

Leoni LS, Tinte VA. 2004. Flora do Parque Estadual do Brigadeiro: caracterização da vegetação e lista preliminar das espécies. Universidade Estadual de Minas Gerais, Carangola. 91p.

Meirelles ST, Pivello VR, Joly CA. The vegetation of granite rock outcrops in Rio de Janeiro, Brazil, and the need for its protection. Environmental Conservation, 26(1): 10-20, 1999.

Mendonça MP. 2013. O Resgate da Flora de Canga. Belo Horizonte, Minas Gerais. Valor Natural. 104p.

Menezes LFT de, Araujo DSD de. Estrutura de duas formações vegetais do cordão externo da Restinga de Marambaia, RJ. Acta Botanica Brasilica, 13(2): 223-235, 1999. 
Menini Neto L, Alves RJV, Barros F, Forzza RC. Orchidaceae do Parque Estadual de Ibitipoca, MG, Brasil. Acta Bot. Bras, 21(3): 687-696, 2007.

Moraes FT. 2008. Zoneamento geoambiental do planalto de Poços de Caldas, MG/SP a partir de análise fisiográfica e pedoestratigráfica. Tese de Doutorado. Universidade Estadual Paulista, Rio Claro. 173p.

Moraes FT, Jiménez-Rueda JR. Fisiografia da região do planalto de Poços de Caldas, MG/SP. Revista Brasileira de Geociências: 38(1): 196-208, 2008.

Myers N, Mittermeier RA, Mittermeier CG, da Fonseca GA, Kent J. Biodiversity hotspots for conservation priorities. Nature, 403: 853-858, 2000.

Pinto SIC, Souza AM, Carvalho D. Variabilidade genética por isoenzimas em populações de Copaifera langsdorffi Desf. em dois fragmentos de mata ciliar. Scientia Forestalis, 65: 40-48, 2004.

Pirani JR, Mello-Silva R, Giulietti AM. Flora de Grão-Mogol, Minas Gerais, Brasil. Bol. Bot. Univ., 21: 1-24, 2003.

Porembski S, Fischer E, Biedinger N. Vegetation of Inselbergs, Quarzitic Outcrops and Ferricretes in Rwanda and Eastern Zaire (Kivu). Bulletin du Jardin Botanique National de Belgique, 66: 81-99, 1997.

Rezende MG, Elias RCL, Salimena FRG, Menini Neto L. Flora vascular da Serra da Pedra Branca, Caldas, Minas Gerais e relações florísticas com áreas de altitude da Região Sudeste do Brasil. Biota Neotropica, 13(4): 201-224, 2013.
Rizzini CT. 1979. Tratado de fitogeografia do Brasil. 2 ed. HUCITEC/Universidade de São Paulo. 374p.

Rosa AEM. 2011. Revisitação de Bromeliaceae na APA Santuário Ecológico da Pedra Branca, Caldas, MG. Dissertação de Mestrado. Universidade Estadual Paulista - UNESP. Rio Claro. 100p.

Safford HD. Brazilian Páramos I. An introduction to the physical environment and vegetation of the campos de altitude. J. Biogeogr., 26: 693-712, 1999.

Salimena FRG, Matozinhos CN, Abreu NL, Ribeiro JHC, Menini Neto L. Flora fanerogâmica da Serra Negra, Minas Gerais, Brasil. Rodriguésia, 64(2): 311320, 2013.

Salles DM, Carmo FF, Jacobi CM. Habitat Loss Challenges the Conservation of Endemic Plants in Mining-Targeted Brazilian Mountains. Environmental Conservation, 46: 140-146, 2019.

Scarano FR. Rock outcrop vegetation in Brazil: a brief overview. Rev. Bras. Bot., 30(4): 561-568, 2007.

Siefert A, Ravenscroft C, Althoff D, Alvarez-Yépis JC, Carter BE, Glennon KL., ... Fridley JD. Scale dependence of vegetation - environment relationships: a meta analysis of multivariate data. Journal of Vegetation Science, 23(5): 942-951, 2012.

Vleminckx J, Drouet T, Amani C, Lisingo J, Lejoly J, Hardy OJ. Impact of fine-scale edaphic heterogeneity on tree species assembly in a central African rainforest. Journal of Vegetation Science, 26(1): 134-144, 2015.

Biodiversidade Brasileira - BioBrasil.

Edição temática: Diálogos entre a Academia e a Gestão de Áreas Protegidas:

Programa de Pós-Graduação Profissional - Biodiversidade em Unidades de Conservação

$$
\text { n. 2, } 2020
$$

http://www.icmbio.gov.br/revistaeletronica/index.php/BioBR

Biodiversidade Brasileira é uma publicação eletrônica científica do Instituto Chico Mendes de

Conservação da Biodiversidade (ICMBio) que tem como objetivo fomentar a discussão e a disseminação de experiências em conservação e manejo, com foco em unidades de conservação $e$ espécies ameaçadas.

ISSN: 2236-2886 